unrelated defects may be the result of a common mechanism: altered neural crest cell migration. Further embryonic and genetic experimentation will likely clarify the role of the neural crest cell at the various levels of cardiac development.

\section{References}

1. Nagao GI, Daoud GI, McAdams AJ, Schwarts DC, Kaplan S. Cardiovascular anomalies associated with tetralogy of Fallot. Am J Cardiol. 1967;20:206-15.
2. Elami A, Rein AJ, Preminger TJ, Milgalter E. Tetralogy of Fallot, absent pulmonary valve, partial anomalous pulmonary venous return and coarctation of the aorta. Int J Cardiol. 1996;52:203-6.

3. Rudolph AM, Heyman MA, Spitznas U. Haemodynamic considerations in the development of narrowing of the aorta. Am J Cardiol. 1972;30: $514-25$.

4. Skoda. Quoted by Hochhaus H. Ueber das Offenbleiben des Ductus Botalli. Deutsch Arch Klin Med.1893;51:1-10.

5. Houston MR, Kirby ML. Neural crest and cardiovascular development: a 20-year perspective. Birth Defects Res Part C Embryo Today. 2003;60(1):2-13

\title{
Novel management strategy for severe cyanosis after Sano modification of the Norwood procedure
}

\author{
Janet M. Simsic, MD, ${ }^{a}$ Angel Cuadrado, MD, ${ }^{\text {a }}$ Paul M. Kirshbom, MD, ${ }^{\text {b }}$ Kirk R. Kanter, MD, ${ }^{\text {b }}$ \\ Donna Ramaswamy, MPH, MS, ${ }^{a}$ Martha Clabby, MD, ${ }^{a}$ and Joseph M. Forbess, MD, ${ }^{\text {b* }}$ Atlanta, Ga
}

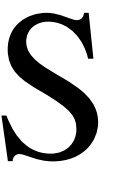

ano modification of the Norwood procedure has resulted in a more favorable distribution of systemic, pulmonary, and coronary blood flow. However, frequently these patients present with severe cyanosis caused by dynamic proximal shunt stenosis. The purpose of this review was to evaluate a management strategy for severe cyanosis in this patient population.

\section{Methods}

Between September 2003 and September 2004, 22 newborns underwent Sano modification at Children's Healthcare of Atlanta. One patient died before hospital discharge and was excluded from further analysis. Four (19\%) of the 21 remaining patients presented at $53 \pm 26$ days of age with oxygen saturations of less than $70 \%$. These 4 patients (group 1) were compared with the remaining 17 (group 2). Management strategy to treat cyanosis in group 1 patients consisted of increasing preload and $\beta$-blockade. Agematched hemodynamic data were evaluated between group 1 before therapy and group 2; variables before and after therapy in group 1 were also evaluated.

\footnotetext{
From Sibley Heart Center Cardiology/Children's Healthcare of Atlanta ${ }^{\mathrm{a}}$ and the Division of Pediatric Cardiothoracic Surgery, Emory University, ${ }^{b}$ Atlanta, Ga.

Received for publication Dec 7, 2004; accepted for publication Dec 15, 2004.

Address for reprints: Janet M. Simsic, MD, Sibley Heart Center Cardiology, 52 Executive Park South, Suite 5200, Atlanta, GA 30329 (E-mail: simsicj@kidsheart.com).

*Present address: University of Texas Southwestern Medical Center, Dallas, Tex.

J Thorac Cardiovasc Surg 2005;129:1450-1

$0022-5223 / \$ 30.00$

Copyright $\odot 2005$ by The American Association for Thoracic Surgery

doi:10.1016/j.jtcvs.2004.12.009
}

\section{Results}

Sano shunt size was $6 \mathrm{~mm}(\mathrm{n}=3$; birth weight, $>3 \mathrm{~kg})$ and $5 \mathrm{~mm}$ ( $\mathrm{n}=1$; birth weight, $<2 \mathrm{~kg}$; group 1) versus a shunt size of $6 \mathrm{~mm}$ ( $\mathrm{n}=13 ; 4$ patients with a birth weight $<3 \mathrm{~kg}$; 9 patients with a birth weight $>3 \mathrm{~kg})$ and $5 \mathrm{~mm}(\mathrm{n}=4$; birth weight, $<3 \mathrm{~kg}$; group 2). Hemodynamic variables before and after therapy in group 1 are shown in Table 1. In addition, comparison was made between hemodynamic variables at the time of presentation with cyanosis group 1 and group 2 at the same age (Table 2).

This management strategy prolonged the timing to bidirectional Glenn shunt by $70 \pm 40$ days in group 1 . A bidirectional Glenn shunt was performed at $123 \pm 32$ days in group 1 (4/4 patients) versus $133 \pm 28$ days in group $2(11 / 13$ patients, $P=.6)$.

\section{Discussion}

Secondary to the variable pulmonary and systemic vascular resistance ratio, the net effect of the Norwood procedure with a systemic-pulmonary artery shunt is runoff from the systemic to the pulmonary bed during diastole, resulting in a low diastolic blood pressure, a wider pulse pressure, and a change in the pattern of

TABLE 1. Hemodynamic variables before and after therapy in group 1

\begin{tabular}{lccc}
\hline & $\begin{array}{c}\text { Before } \\
\text { therapy }\end{array}$ & $\begin{array}{c}\text { After } \\
\text { therapy }\end{array}$ & $\boldsymbol{P}$ value \\
\hline No. of patients & 4 & 4 & 1.0 \\
Oxygen saturation (\%) & $62 \pm 9$ & $80 \pm 3$ & .01 \\
Heart rate (beats/min) & $151 \pm 13$ & $129 \pm 9$ & .03 \\
Respiratory rate (breaths/min) & $60 \pm 10$ & $50 \pm 22$ & .4 \\
Systolic blood pressure (mm Hg) & $90 \pm 1$ & $90 \pm 12$ & 1.0 \\
Diastolic blood pressure $(\mathrm{mm} \mathrm{Hg})$ & $44 \pm 8$ & $49 \pm 13$ & .5 \\
Mean blood pressure $(\mathrm{mm} \mathrm{Hg})$ & $60 \pm 5$ & $63 \pm 11$ & .5 \\
RVOT proximal gradient $(\mathrm{mm} \mathrm{Hg})$ & $92 \pm 12$ & $58 \pm 13$ & .02 \\
\hline
\end{tabular}

Mean $\pm \mathrm{SD}$; paired 2-tailed $t$ test. RVOT, Right ventricular outflow tract. 
TABLE 2. Hemodynamic variables at the time of presentation with cyanosis in group 1 and patients in group 2 at the same age

\begin{tabular}{lccc}
\hline & Group 1 & Group 2 & P value \\
\hline No. of patients & 4 & 17 & \\
Age at the time of the operation (d) & $5 \pm 3$ & $5 \pm 3$ & 1.0 \\
Birth weight (kg) & $3.1 \pm 0.8$ & $3.2 \pm 0.5$ & 1.0 \\
Cardiopulmonary bypass time (min) & $135 \pm 16$ & $147 \pm 28$ & .3 \\
Total ischemic time (min) & $60 \pm 3$ & $65 \pm 14$ & .1 \\
Age with cyanosis (d) & $53 \pm 26$ & $56 \pm 13$ & .8 \\
Oxygen saturation (\%) & $62 \pm 9$ & $80 \pm 3$ & .02 \\
Heart rate (beats/min) & $151 \pm 13$ & $142 \pm 11$ & .3 \\
Respiratory rate (beats/min) & $60 \pm 10$ & $52 \pm 11$ & .3 \\
Systolic blood pressure (mm Hg) & $90 \pm 1$ & $85 \pm 8$ & .5 \\
Diastolic blood pressure (mm Hg) & $44 \pm 8$ & $48 \pm 8$ & .5 \\
Mean blood pressure (mm Hg) & $60 \pm 5$ & $60 \pm 7$ & .9 \\
RVOT proximal gradient $(\mathrm{mm} \mathrm{Hg})$ & $92 \pm 12$ & $44 \pm 17$ & .0003 \\
\hline
\end{tabular}

Mean \pm SD; paired 2-tailed $t$ test. RVOT, Right ventricular outflow tract.

coronary perfusion. ${ }^{1}$ Sano modification, substituting a right ventricle-pulmonary artery shunt in place of the systemic-pulmonary artery shunt, provides a more favorable distribution of systemic, pulmonary, and coronary blood flow. Several studies have reported a hemodynamic profile with higher diastolic pressure, ${ }^{2,3}$ narrowed pulse pressure, ${ }^{2,3}$ and higher coronary perfusion pressure ${ }^{2}$ after a right ventricle-pulmonary artery shunt compared with that after a systemic-pulmonary artery shunt.

In our recent experience, 4 (19\%) of 21 patients after Sano modification presented at $53 \pm 26$ days of age with systemic oxygen saturation of less than $70 \%$ caused by dynamic proximal shunt stenosis. The proximal shunt Doppler gradient determined by transthoracic echocardiography was $92 \pm 12 \mathrm{~mm} \mathrm{Hg}$. The gradient was due to dynamic obstruction below the ventricular anastomosis site of the right ventricle-pulmonary artery shunt. We believe that this mechanism of significant cyanosis after the Sano modification is similar to that of hypercyanotic episodes in tetralogy of Fallot: dynamic outflow obstruction. Therefore, we adopted a management strategy of increased preload and $\beta$-blockade similar to the treatment strategy for the hypercyanotic episode in patients with tetralogy of Fallot.

Increasing preload was achieved by volume bolus ( 3 patients) and decreasing diuretic therapy (4 patients). $\beta$-Blockade therapy was with propranolol $\left(1 \mathrm{mg} \cdot \mathrm{kg}^{-1} \cdot \mathrm{d}^{-1}\right)$ in 3 patients and esmolol in 1 patient. This patient was converted to sotalol instead of propranolol because of atrial dysrhythmias not responsive to propranolol. This combination therapy resulted in a $22 \%$ increase in systemic oxygen saturation (from $62 \% \pm 9 \%$ to $80 \% \pm 3 \%$ ), with a $15 \%$ decrease in heart rate (from $151 \pm 13$ to $129 \pm 9$ beats/min).

Increased preload in these single-ventricle patients results in increased systemic resistance, allowing more blood flow into the pulmonary circuit. Increased cardiac output and pulmonary blood flow leads to increased systemic oxygen saturations. $\beta$-Blocker therapy has been shown to increase systemic saturation in patients with tetralogy of Fallot through a variety of complex mechanisms, including increases in peripheral resistance, ${ }^{4}$ prevention of tachycardia, and shift in the hemoglobin-oxygen dissociation curve. ${ }^{5}$ Increased peripheral resistance again allows for increased pulmonary blood flow in this single-ventricle patient. A slower heart rate allows for increased ventricular filling time and thus increased preload. Shifting the hemoglobin-oxygen dissociation curve results in increased availability of oxygen delivery to the tissues. The overall result is improvement in systemic oxygen saturations.

\section{Conclusion}

The medical management strategy of increasing preload and initiating $\beta$-blockade therapy is effective in the treatment of severe cyanosis caused by dynamic proximal shunt stenosis after Sano modification of the Norwood procedure.

\section{References}

1. Vogel MA, Rychik J, Vetter J, Donofrio MT, Jacobs M. Effect of volume unloading surgery on coronary flow dynamics in patients with aortic atresia. J Thorac Cardiovasc Surg. 1997;113:718-27.

2. Maher KO, Pizarro C, Gidding SS, Januszewska K, Malec E, Norwood WI Jr, et al. Hemodynamic profile after the Norwood procedure with right ventricle to pulmonary artery conduit. Circulation. 2003;108: $782-4$

3. Bradley SM, Simsic JM, McQuinn TC, Habib DM, Shirali GS, Atz AM. Hemodynamic status following the Norwood procedure: a comparison of right ventricle to pulmonary artery versus modified Blalock-Taussig shunt. Ann Thorac Surg. 2004;78:933-41.

4. Honey M, Chamberlain DA, Howard J. The effect of beta-sympathetic blockade on arterial oxygen saturation in Fallot's tetralogy. Circulation. 1964;30:501-6.

5. Oski FA, Miller LD, Dellvoria-Papadopoulos M, Manchester JH, Shelburn JC. Oxygen affinity in red cells: changes induced in vivo by propranolol. Science. 1972;175:1372-3. 